\title{
Small-scale spatial variability of selected soil biological properties
}

\author{
C.H.E. Stark ${ }^{\mathrm{a}}$, L.M. Condron ${ }^{\mathrm{a}, *}$, A. Stewart ${ }^{\mathrm{b}}$, H.J. Di ${ }^{\mathrm{a}}$, M. O’Callaghan ${ }^{\mathrm{c}}$ \\ ${ }^{a}$ Soil, Plant \& Ecological Sciences Division, PO Box 84, Lincoln University, Canterbury, New \\ Zealand \\ ${ }^{\mathrm{b}}$ National Centre for Advanced Bio-protection Technologies, PO Box 84, Lincoln University, \\ Canterbury, New Zealand \\ ${ }^{c}$ AgResearch, PO Box 60, Lincoln, Canterbury, New Zealand
}

\begin{abstract}
A strategy for sampling soil from intact monolith lysimeters was established based on measurements of spatial heterogeneity within the lysimeter area. This was part of an ongoing study to determine relationships between soil microbial diversity and nutrient loss by leaching. The sampling protocol had to allow for collection of soil on a regular basis (as opposed to destructive sampling) and ensure high spatial independence of subsamples. On each of two sites (one developed under organic crop management, the other under conventional crop management), ten $15-\mathrm{cm}$ soil cores (sampling points) were taken from three areas (replicates) of 50-cm-diameter (lysimeter surface area) and separately analysed for biotic (microbial biomass carbon and nitrogen; arginine deaminase activity) and abiotic (total carbon and nitrogen) soil properties. The data was tested for variability, expressed as coefficient of variance (biotic and abiotic), and spatial heterogeneity using geostatistics (biotic properties). The biotic soil properties showed significant differences among sampling points, whereas the abiotic parameters were useful in differentiating on a larger scale, i.e. between sites. For all soil properties tested, the differences among the replicates were smaller than those between sites or among points indicating that, in the main experiment, all treatments can be sampled following the same pattern.Geostatistical analysis and fitting of an exponential model showed that a spatial structure exists in the biotic soil properties and that the samples are independent beyond separation distances of $25-30 \mathrm{~cm}$. A revised sampling pattern consisting of 11 samples per lysimeter is described.
\end{abstract}

\section{Keywords}

Small-scale spatial variability; Intact monolith lysimeters; Sampling pattern; Microbial biomass carbon; Microbial biomass nitrogen; Arginine deaminase activity

\footnotetext{
* Corresponding author. Tel.: +64-3-3252811; fax: +64-3-3253607; E-mail address: CONDRONL@lincoln.ac.nz
} 


\section{Introduction}

It is widely accepted that soil biota play a vital role in the maintenance of soil fertility and productivity. Although we are able to appreciate the significance of microorganisms in the soil we have little information on the role microbial community structure and function play in determining sustainability and functioning of soil ecosystems (Ritz et al., 1994; Insam and Rangger, 1997). Microbial diversity in soil is influenced by a number of factors, including soil properties, environmental conditions and anthropogenic activities. It is, thus, likely that changing management practices can have significant and lasting effects on the functioning of the soil microbial community and the ecosystem as a whole (Waldrop et al., 2000; O'Donnell et al., 2001). Improved understanding of soil microbial diversity and function may enhance our ability to manipulate nutrient cycling and retention in situ in order to maintain and improve soil quality and sustainability (Kennedy and Gewin, 1997; Bending et al., 2000).

One way of investigating relationships between microbial diversity (including community composition, activity and function), and how it relates to nutrient cycling and its associated environmental impacts is by using intact monolith lysimeters (e.g. Cameron et al., 1992; Di et al., 1998; Turner and Haygarth, 2000; Riley et al., 2002). Small to medium sized monolith lysimeters (surface area of 0.2 to $0.5 \mathrm{~m}^{2}$ ) can provide all the benefits of a pot trial, including better control over irrigation, pests and weeds than can be achieved in the field, together with the potential to measure leaching and gaseous losses.

The present study is part of an ongoing experiment that uses intact monolith lysimeters $(50 \mathrm{~cm}$ diameter; $70 \mathrm{~cm}$ deep) of the same soil type taken from adjacent sites under long-term organic and conventional management and involves measurement of nitrogen $(\mathrm{N})$ loss by leaching together with determination of a range of biological and chemical soil properties.

Protocols have been established to take soil from different depths in the lysimeters by destructive sampling (Fraser et al., 1994; Cookson et al., 2001). However, it is not common practice to repeatedly take in situ soil samples from undisturbed monolith lysimeters since the type and size of lysimeters used in this study are more commonly maintained under grassland where sampling would create preferential flow pathways (e.g. Bidwell, 2000; Stout et al., 2000; Turner and Haygarth, 2000; Di and Cameron, 2002). A thorough review of the literature revealed no published studies on sampling strategies for intact monolith lysimeters of the size used in this study (c. $0.2 \mathrm{~m}^{2}$ ). The relatively small surface area and volume of the lysimeters can be seen as the main factors limiting the number of samples that can be taken from the lysimeter at any one time without ultimately compromising the experiment.

The objective of the study presented in this paper was to develop and evaluate a strategy for regular sampling of soil from lysimeters by measuring variance and spatial variability for a range of soil biological parameters and analysing them by means of geostatistics. The results also have implications for field sampling in terms of appropriate distances between sampling points.

\section{Materials and Methods}

\section{Context}

Two sites, approximately $2 \mathrm{~km}$ apart, were identified within the cropping farm at Lincoln University (Canterbury, New Zealand) that had been farmed under contrasting 'organic' and 'conventional' management systems for around 25 years. The organic site (ORG) was established in 1976, while the conventional site (CON) had been maintained under intensive mixed cropping for over 100 years. The soil at both sites was a Wakanui silt loam (free draining to $75 \mathrm{~cm}$ ) (Mottled Immature Pallic Soil, NZ classification; Udic Ustochrept, USDA). 
In November 2001, eight replicate intact monolith lysimeters (50 $\mathrm{cm}$ diameter by $70 \mathrm{~cm}$ deep) in steel casings were taken from each site, and installed in the lysimeter laboratory according to the protocol established (Cameron et al., 1992; Di and Cameron, 2002). The lysimeters will be maintained under organic and conventional cropping regimes for a minimum of 5 years and soil samples will be taken on a regular basis (bulked) to investigate relationships between soil microbial activity and nutrient loss.

\section{Spatial variability study}

The spatial variability study was carried out at ORG and CON on areas of soil equivalent to the lysimeters described above. In April 2002, 10 soil samples were taken within each of three 50-cmdiameter areas (surface area of a lysimeter) in a distinctive pattern (Fig. 1) and a range of soil properties was tested to determine spatial variation within each area. The three sampling areas were placed at distances of approximately 70 to $90 \mathrm{~cm}$ from each other (distance from the centre of one area to the centre of the other). This corresponded to the distance between the monoliths when the lysimeters were collected. The soil properties were measured in duplicate in each of 60 soil cores ( $2.5 \mathrm{~cm}$ diameter; $15 \mathrm{~cm}$ depth) - two sites, three areas per site (replicates), ten sample points per replicate (positions). The design of the sampling pattern was based on two main constraints: the limited area $\left(\right.$ c. $0.2 \mathrm{~m}^{2}$ ) and volume of the lysimeters, and the requirement of a relatively large number of samples and distance comparisons to guarantee meaningful geostatistical analysis. The selected pattern ensured a variety of distances between sampling points resulting in 10 to $40 \mathrm{~cm}$ distance comparisons.

\section{Soil analyses}

The samples were passed through a 4-mm mesh and plant material and roots were removed. Sieved samples were stored at $4^{\circ} \mathrm{C}$ in the dark for up to three weeks until analyses took place. Microbial biomass carbon $\left(\mathrm{C}_{\text {mic }}\right)$ and nitrogen $\left(\mathrm{N}_{\text {mic }}\right)$ were estimated by fumigation extraction following the method of Sparling and West (1988). For conversion of $\mathrm{C}$ and $\mathrm{N}$ to $\mathrm{C}_{\mathrm{mic}}$ and $\mathrm{N}_{\text {mic }}$, factors of $k_{\mathrm{eC}}=0.35$ (Sparling et al., 1990) and $k_{\mathrm{eN}}=0.54$ (Brookes et al., 1985) were used, respectively. Arginine deaminase activity (or arginine ammonification) (ADA) was measured using a modification of the method of Alef and Kleiner (1987) as described in Alef and Nannipieri (1995). Following extraction with $2 \mathrm{M} \mathrm{KCl}$, ammonium-N $\left(\mathrm{NH}_{4}-\mathrm{N}\right)$ content in the samples was determined by automated flow injection analysis (Tecator, Sweden). Total carbon $\left(\mathrm{C}_{\text {tot }}\right)$ and nitrogen $\left(\mathrm{N}_{\text {tot }}\right)$ were measured in air-dried and sieved samples (2-mm mesh) on a Leco ${ }^{\circledR}$ CNS-2000 elemental analyser.

\section{Statistical analysis}

Variation in biotic and abiotic soil parameters was determined in soils from ORG and CON by calculating coefficients of variance between positions (sampling points within each area), replicates (sampling areas) and the two sites. These different levels of variance were determined for the soil properties $\mathrm{C}_{\text {mic }}, \mathrm{N}_{\text {mic }}, \mathrm{ADA}, \mathrm{C}_{\text {tot }}$, and $\mathrm{N}_{\text {tot }}$ and some ratios of these (microbial carbon: nitrogen ratio $\left[\mathrm{C}_{\text {mic }} / \mathrm{N}_{\text {mic }}\right]$; total carbon: total nitrogen ratio $[\mathrm{C} / \mathrm{N}]$; microbial carbon: total carbon ratio $\left[\mathrm{C}_{\text {mic }} / \mathrm{C}_{\text {tot }}\right]$ ).

Geostatistical methods were applied to study spatial variability of the soil properties (Goovaerts, 1998; Legendre and Legendre, 1998) (Eq. 1):

$$
\gamma(\mathrm{h})=\frac{1}{2 \mathrm{~N}(\mathrm{~h})} \sum_{\mathrm{i}=1}^{\mathrm{n}}\left[\mathrm{z}\left(\mathrm{s}_{\mathrm{i}}\right)-\mathrm{z}\left(\mathrm{s}_{\mathrm{i}}+\mathrm{h}\right)\right]^{2}
$$


where $\gamma(\mathrm{h})=$ semivariance at a given distance $\mathrm{h}$;

$\mathrm{N}(\mathrm{h})=$ number of observation pairs for a given distance $\mathrm{h}$;

$\mathrm{z}\left(\mathrm{s}_{\mathrm{i}}\right)=$ value of respective soil property at sampling point $\mathrm{s}_{\mathrm{i}}$;

$\mathrm{z}\left(\mathrm{s}_{\mathrm{i}}+\mathrm{h}\right)=$ value of soil property at a sampling point with the distance $\mathrm{h}$ from $\mathrm{s}_{\mathrm{i}}$.

Based on frequency distributions (cf. Section 3.2), $\mathrm{C}_{\text {mic }}, \mathrm{N}_{\text {mic }}$, and ADA data were used to measure autocorrelation of positions and estimate semivariograms. For each soil property, semivariance was calculated for ORG, CON and for the average of the two.

Five distance classes were established, $10 \mathrm{~cm}$ (consisting of comparisons where $\mathrm{h}=10 \mathrm{~cm}$; $\mathrm{N}(\mathrm{h})=18), 15 \mathrm{~cm}(\mathrm{~h}=14.1-15.3 \mathrm{~cm} ; \mathrm{N}(\mathrm{h})=42), 20 \mathrm{~cm}(\mathrm{~h}=20 \mathrm{~cm} ; \mathrm{N}(\mathrm{h})=33), 30 \mathrm{~cm}(\mathrm{~h}=28-30 \mathrm{~cm}$; $\mathrm{N}(\mathrm{h})=33)$ and $40 \mathrm{~cm}(\mathrm{~h}=37-40 \mathrm{~cm} ; \mathrm{N}(\mathrm{h})=9)$. Due to the limitations in sampling area and removable soil volume, a sampling plan consisting of 10 samples was chosen; as a result the rule of thumb (at least 30 observation pairs per distance class (Stein and Ettema, 2003)) could not be fulfilled for all distance classes.

Semivariograms for the three soil properties were fitted with an exponential model (based on Eq. 2), which allowed the spatial dependence for the respective soil properties to be determined (Legendre and Legendre, 1998).

$$
y=C_{0}+C_{1}\left(1-\exp ^{(-3 x / a)}\right)
$$

where $\mathrm{y}=$ semivariance;

$\mathrm{x}=$ distance between sampling points;

$\mathrm{C}_{0}=$ nugget or intercept, i.e. the level of variability at distance $\mathrm{h}=0 \mathrm{~cm}$;

$\mathrm{C}_{1}=$ component related to the spatial pattern of the model;

$\mathrm{a}=$ range, i.e. distance between sampling points at which asymptote is reached.

If spatial dependence exists, it is possible to fit an exponential model and the data will show low levels of variance for short separation distances (in this case $10 \mathrm{~cm}$ ), followed by an increase until the asymptote is reached at a distance a (range). Beyond the range, the semivariance measured for the data points is independent from the respective separation distance. The sill $\left(\mathrm{C}=\mathrm{C}_{0}+\mathrm{C}_{1}\right.$ [Eq. 1]) indicates the variance of the asymptote and signifies the total variance of the model.

The decreasing number of pairs of observations with increasing distance between sampling points can result in too few comparisons to achieve sound results. In this case, it was possible to fit the model effectively to data derived from sampling points with separation distances from 0 to $40 \mathrm{~cm}$ for ORG and average, while for CON only points from the $30 \mathrm{~cm}$ - distance class were included.

The data were analysed using general linear model analysis of variance in Minitab ${ }^{\circledR}$ for Windows Release 13.1 (@2000, Minitab Inc., USA). Regressions were performed in Sigmaplot for Windows Version 5.00 (C) 1986-1999, SPSS, Inc.) and $\mathrm{R}^{2}$ was used to measure goodness of fit of data to the exponential model.

\section{Results}

\section{Variance between sites, replicates, and positions}

For $\mathrm{C}_{\text {mic }}, \mathrm{N}_{\text {mic }}$ and $\mathrm{ADA}$, the variability among the 10 positions within each area, expressed as coefficients of variance of the mean value $(\mathrm{CV})$, was highest $\left(\mathrm{CV}_{\text {position }}: 78.6 \%\left[\mathrm{C}_{\text {mic }}\right] ; 56.1 \%\left[\mathrm{~N}_{\text {mic }}\right]\right.$; $50.4 \%$ [ADA] ) (Fig. 2). For $\mathrm{C}_{\text {mic }}$ and $\mathrm{N}_{\text {mic }}$, this was followed by the variability between the areas 
within each site $\left(\mathrm{CV}_{\text {area }}\right)$. ADA showed a similar variability between sites $\left(\mathrm{CV}_{\text {site }}\right)$ as among the 10 positions, while $\mathrm{CV}_{\text {area }}$ was smaller than the other two $(<5 \%)$. For $\mathrm{C}_{\text {mic }} / \mathrm{N}_{\text {mic }}, \mathrm{CV}_{\text {site }}$ was highest (46.6\%), while $\mathrm{CV}_{\text {area }}$ and $\mathrm{CV}_{\text {position }}$ were both around $27 \%$. For $\mathrm{C}_{\text {mic }}$ and $\mathrm{N}_{\text {mic }}, \mathrm{CV}_{\text {site }}$ was regarded as zero based on the observation that in both cases the mean squares (MSq) for the sites were smaller than for the replicates.

The patterns of variability were similar for $\mathrm{C}_{\text {tot }}$ and $\mathrm{N}_{\text {tot }}$ and, consequently $\mathrm{C}_{\text {mic }} / \mathrm{C}_{\text {tot }}$ and $\mathrm{C} / \mathrm{N}$. $\mathrm{CV}_{\text {position }}$ was larger than $\mathrm{CV}_{\text {area }}$ (tendency towards zero for $\mathrm{C}_{\text {tot }}$ and $\mathrm{N}_{\text {tot }}$ ), while the highest degree of variance could be observed for site (Fig. 2). For $\mathrm{C}_{\text {tot, }}$, the error mean square was bigger than the mean square for the effect "area (site)" (replicates within each site). Consequently, the calculated $\mathrm{CV}$ was negative and was regarded as zero.

The average values of the biotic soil properties $\left(\mathrm{C}_{\text {mic }}, \mathrm{N}_{\text {mic }}, \mathrm{ADA}\right)$ show that $\mathrm{CV}_{\text {site }}$ was smaller than $\mathrm{CV}_{\text {area }}$ and $\mathrm{CV}_{\text {position }}(23.4 \%$ as compared to $23.8 \%$ and $52.8 \%$, respectively) whereas the average CVs of the abiotic soil properties $\left(\mathrm{C}_{\text {tot }}, \mathrm{N}_{\text {tot }}\right)$ show the differences between sites were larger $(81.5 \%)$ than between positions (13.7\%) (Fig. 2). For the average of chemical soil properties, $\mathrm{CV}_{\text {area }}$ was smallest with $4.9 \%$.

This pattern is supported by the results presented in Table 1. The biotic soil properties measured in this experiment $\left(\mathrm{C}_{\text {mic }}, \mathrm{N}_{\text {mic }}\right.$, $\mathrm{ADA}$ and $\left.\mathrm{C}_{\text {mic }} / \mathrm{N}_{\text {mic }}\right)$ were able to differentiate between the positions in each replicate on a significant level. All but one property $\left(\mathrm{C}_{\text {mic }}\right)$ were able to detect significant differences between the sites, and this effect was highly significant for $\mathrm{C}_{\text {mic }} / \mathrm{N}_{\text {mic }}$ and $\mathrm{C}_{\text {mic }} / \mathrm{C}_{\text {tot }}$, as well as for the abiotic soil properties $\mathrm{C}_{\text {tot }}, \mathrm{N}_{\text {tot }}$ and $\mathrm{C} / \mathrm{N}(\mathrm{P}<0.001)$. This indicated that measuring abiotic rather than biotic soil properties best separated the two sites.

Comparing the mean square values for site and area (site) supports these findings. For the soil properties that showed significant differences between sites, the mean square value for site $\left(\mathrm{MSq}_{\text {site }}\right)$ was bigger than the mean square value for areas within sites $\left(\mathrm{Msq}_{\text {area }}(\mathrm{site})\right)$ (Table 1$)$. On the other hand, $\mathrm{Msq}_{\text {area (site) }}$ is expected to be greater than $\mathrm{MSq}_{\text {site }}$ when differences between replicates are more pronounced than between sites. In this case, variability between sites was regarded as zero $\left(\mathrm{C}_{\text {mic }}\right.$ and $\left.\mathrm{N}_{\text {mic }}\right)$, as the main purpose of this study was to evaluate the spatial variability within each area (i.e. between positions).

As mentioned above, site had a significant effect on all but one property $\left(\mathrm{C}_{\text {mic }}\right)$. The mean values indicated that a significantly higher ADA activity was measured on ORG. Similarly, there were higher contents of $\mathrm{N}_{\text {mic }}$, a higher microbial quotient $\left(\mathrm{C}_{\mathrm{mic}} / \mathrm{C}_{\text {tot }}\right)$ and higher $\mathrm{C} / \mathrm{N}$ ratio $(\mathrm{P}<0.001$ in both cases). $C O N$ showed higher levels of $\mathrm{C}_{\text {tot }}, \mathrm{N}_{\text {tot }}\left(\mathrm{P}<0.001\right.$ in both cases) and $\mathrm{C}_{\text {mic }}$ (not significant) (Table 2).

Looking at the levels of significance of the three effects on average biotic and abiotic soil parameters, respectively, biotic soil characteristics detected highly significant differences among the positions within each area and among areas within each site (Table 3 ). The abiotic soil properties on the other hand revealed significant differences between sites, while they did not distinguish between the replicates within each site. These findings are supported by the results displayed in Table 1 and Fig. 2.

\section{Spatial pattern determination}

\section{Frequency distribution}

Across the 60 sampling points at six sampling locations, ADA varied intensely (data range $=1.6 \mu \mathrm{g} \mathrm{NH}_{4}-\mathrm{N} \mathrm{g}^{-1} \mathrm{~h}^{-1} ; \mathrm{CV}=22.5 \%$ ) and displayed a strong positive skew. Tests for normality suggest that the data was randomly distributed; hence, the changes in value seemed to be independent from the respective sampling locations (Table 4). 
For $\mathrm{C}_{\text {mic }}$, values covered a range of $420 \mu \mathrm{g} \mathrm{C} \mathrm{g}^{-1}$ soil and showed a coefficient of variance of $0.77 \%$. The frequency distributions for $\mathrm{C}_{\text {mic }}$ showed a slight positive skew. $\mathrm{N}_{\text {mic }}$ concentrations ranged over $70 \mu \mathrm{g} \mathrm{N} \mathrm{g}^{-1}$ with a standard variation of $16.4 \mu \mathrm{g} \mathrm{g}^{-1}$. The coefficient of skewness for the frequency distribution was 0.32 . Tests for normality showed that in both cases the frequency distributions can be regarded as being normally distributed (Table 4). This indicates that a dependence exists between change in value and increasing sampling point distance.

For $\mathrm{C}_{\text {tot }}$ and $\mathrm{N}_{\text {tot }}$, the frequency distributions were totally random (results not shown) indicating no correlation exists between sampling location and change in value for these parameters within the scale sampled; hence, only $\mathrm{C}_{\text {mic }}, \mathrm{N}_{\text {mic }}$ and $\mathrm{ADA}$ were tested for semivariance.

\section{Spatial variability}

Looking at the development of semivariance in $\mathrm{C}_{\text {mic }}$ and $\mathrm{N}_{\text {mic }}$ for ORG, CON and the average of the two with increasing distance between sampling points, it can be noticed that CON showed much lower levels of semivariance than ORG in both, $\mathrm{C}_{\text {mic }}$ and $\mathrm{N}_{\text {mic }}$ (Fig. 3). The exponential model, however, suggested a bigger nugget (intercept) for CON than ORG and average. In all cases, the model represented the observed amounts of variance sufficiently well, although CON showed low values for spatial dependence and $\mathrm{R}^{2}$ (Table 5).

In ADA, the exponential models did not match the data as well as they did for the other two soil properties. For ORG, high value for the sill could be observed compared to the initial value. As shown in Fig. 3, the curve does not reach its asymptote within the displayed range. For ORG, CON and average the estimated range was higher in ADA than in $\mathrm{C}_{\text {mic }}$ and $\mathrm{N}_{\text {mic }}$. And while values for spatial dependence were within the same range as for the other two properties, $\mathrm{R}^{2}<0.9$ and $\mathrm{P}>0.05$ indicate that the regression was not significant for ORG, CON and average (Table 5).

\section{Discussion}

It is well known that soils vary spatially even over short distances. Spatial variability is understood to have an effect on transport processes in soils, e.g. of organic pollutants (Søvik and Aagaard, 2003), biomass turnover rate (Harden and Joergensen, 2000) and on nutrient cycling processes (de Boer et al., 1996; Corre et al., 2002). Consequently, assessing the spatial structure of a site will help developing better nutrient management strategies, and can serve as a means designing suitable sampling patterns (Ettema and Wardle, 2002; Franklin et al., 2002; Stein and Ettema, 2003). Soil spatial structure has been investigated at different scales $(\mathrm{cm}, \mathrm{m}, \mathrm{km})$ and with different objectives. Most studies on spatial variability have concentrated on aboveground biota and abiotic soil properties, e.g. soil moisture, hydraulic conductivity, temperature (Bruckner et al., 1999; Al-Kayssi, 2002; Søvik and Aagaard, 2003). Nonetheless, an increasing number of studies have begun to examine heterogeneity of biological soil properties in general and the microbial community in particular (Morris, 1999; Harden and Joergensen, 2000; Corre et al., 2002; Franklin et al., 2002; Nunan et al., 2002; Ettema and Yeates, 2003). Depending on the scale, spatial structure in microbial soil properties is influenced by land use, soil carbon content, topography, plant cover (including form, size, spacing), soil aggregates, fine roots, and substrate hotspots (Ettema and Wardle, 2002). This implies the importance of determining spatial variability even within small areas in order to obtain meaningful bulk samples. However, literature revealed no evidence of the application of spatial variability data to design a soil sampling strategy for within lysimeters.

The overall goal of this study was to design a protocol that allows soil samples to be taken from intact monolith lysimeters on a regular basis. Therefore, the degree of variance was determined on different levels (between sites, among replicates, among positions) and the pattern of spatial heterogeneity within the area of a lysimeter was established. 
In general, results suggest that the biotic soil properties studied exhibited spatial dependence within the area of a lysimeter. The existence of spatial patterns in biological soil parameters at this scale is consistent with results shown in previous studies (Brockmann and Murray, 1997; Bruckner et al., 1999; Morris, 1999). ORG and CON showed similar patterns of semivariance. However, spatial dependence was much smaller for CON than for ORG (44-64\% as opposed to 82-95\%) (Table 5). This outcome is consistent with the expectation that cultivated soils are spatially less variable since cultivation disrupts the spatial pattern (Goovaerts, 1998; Röver and Kaiser, 1999). CON had been cultivated a short time before sampling took place, whereas ORG had been under herb ley for approximately 18 months. This initial difference should not interfere with sampling during the main experiment given that all lysimeters will be cropped and cultivated in the same way. Therefore, an adjustment of the spatial variability in the soils originating from $\mathrm{CON}$ is to be expected over time.

Patterns for semivariance were similar in $\mathrm{C}_{\text {mic }}$ and $\mathrm{N}_{\text {mic }}$, both reaching the sill within the sampled scale, whereas in ADA, semivariance displayed a different trend. This suggests that for $\mathrm{C}_{\mathrm{mic}}$ and $\mathrm{N}_{\text {mic }}$, samples taken within the area of the lysimeters $(50-\mathrm{cm}$ diameter) are independent from each other when their separation distance exceeds 25 to $30 \mathrm{~cm}$, while, according to the exponential model, for ADA, the samples will not be stochastically independent from each other within the area of the lysimeters. The random distribution of the data points indicates a nugget effect, i.e. the variance is not spatially structured at the scale measured $(10-40 \mathrm{~cm})$. However, spatial dependence could exist below this scale.

Statistical analysis can be problematic for autocorrelated samples since autocorrelation reduces variance within the measured bulk sample and increases variability among samples (Franklin et al., 2002). It is, therefore, important to collect a representative bulk sample that consists of a large number of independent samples in order to make valid statistical analysis possible. Regarding the lysimeter sampling design, this stresses the importance of taking a considerable number of independent subsamples (with separation distances $>20 \mathrm{~cm}$ ). In this study, 10 soil cores were sampled per lysimeter (Fig. 1) resulting in 25 pairs with separation distances of $20 \mathrm{~cm}$ or more, which was sufficient to achieve meaningful results. It will be difficult to largely increase the number of samples that are more than $30 \mathrm{~cm}$ apart given the limited area (c. $0.2 \mathrm{~m}^{2}$ ). However, in order to increase the number of pairs in the distance classes 20,30 and $40 \mathrm{~cm}$, we suggest a sampling regime that consists of 11 soil cores and, consequently, 39 observation pairs per bulk sample (Fig. 4).

It is also important that the samples taken from the different lysimeters are independent to ensure valid statistical analysis. This can be considered to be the case based on the results displayed in Table 5 and Fig. 3, and assuming that the lysimeters have separation distances of more than $50 \mathrm{~cm}$.

The relatively higher values of $\mathrm{CV}_{\text {position }}$ for $\mathrm{C}_{\text {mic }}$ and $\mathrm{N}_{\text {mic }}, \mathrm{ADA}$, and consequently for the average for biotic soil properties, imply that these soil properties can be used to recognise differences on a small spatial scale, i.e. among sampling points up to $40 \mathrm{~cm}$ apart, while abiotic soil properties $\left(\mathrm{C}_{\text {tot }}\right.$ and $\mathrm{N}_{\text {tot }}$ ) are useful for differentiating on a larger scale, in this case between sites $2 \mathrm{~km}$ apart (Fig. 2). The methods showed good reproducibility, there was little variance between the replicates (data not shown) and for all soil parameters the measurable differences among replicates expressed as coefficient of variance were smaller than the differences among positions or sites. Thus, one general sampling strategy can be applied for all treatments and replicates. The results suggest that this is particularly true when assessing biotic soil properties as only minor differences between replicates and sites were detected. The potential of the examined abiotic properties to differentiate between sites will be of advantage after the four different treatments have been imposed on the lysimeters and treatment related effects have to be determined.

In conclusion, the findings of this study showed that

(a) a spatial structure exists in the biotic soil properties at the scale examined with samples being independent beyond separation distances of $25-30 \mathrm{~cm}$; 
(b) measuring biological soil properties $\left(\mathrm{C}_{\text {mic }}, \mathrm{N}_{\text {mic }}, \mathrm{ADA}, \mathrm{C}_{\mathrm{mic}} / \mathrm{N}_{\text {mic }}\right)$ detect differences at a small-scale spatial level $(<0.5 \mathrm{~m})$, whereas abiotic soil properties $\left(\mathrm{C}_{\text {tot }}, \mathrm{N}_{\mathrm{tot}}, \mathrm{C} / \mathrm{N}\right)$ as well as $\mathrm{C}_{\text {mic }} / \mathrm{C}_{\text {tot }}$ can be used to distinguish on a larger scale (between sites, separated by several kilometres);

(c) the differences between replicates can be disregarded when designing a sampling regime for intact monolith lysimeters. Consequently, all lysimeters can be sampled following the same protocol. However, the sampling design should be adjusted and the number of subsamples increased from 10 to 11 to ensure more distance comparisons of $20 \mathrm{~cm}$ and over.

\section{Acknowledgements}

The authors acknowledge the technical assistance provided by Lincoln University Analytical Services. We also thank Dr. Chris Frampton (Lincoln University) for his advice regarding the statistical analysis of the data. Financial support for this study was provided by the New Zealand Fertiliser Manufacturers' Research Association and Lincoln University.

\section{References}

Alef, K., Kleiner, D., 1987. Applicability of arginine ammonification as indicator of microbial activity in different soils. Biology \& Fertility of Soils 5, 148-151.

Alef, K., Nannipieri, P., 1995. Methods in applied soil microbiology and biochemistry. Academic Press Limited, London. 576 pp.

Al-Kayssi, A.W., 2002. Spatial variability of soil temperature under greenhouse conditions. Renewable Energy 27, 453-462.

Bending, G.D., Putland, C., Rayns, F., 2000. Changes in microbial community metabolism and labile organic matter fractions as early indicators of the impact of management on soil biological quality. Biology \& Fertility of Soils 31, 78-84.

Bidwell, V.J., 2000. Decision support for protecting groundwater from land treatment of wastewater. Environmetrics 11, 553-562.

Brockmann, F.J., Murray, C.J., 1997. Subsurface microbiological heterogeneity: current knowledge, descriptive approaches and applications. FEMS Microbiology Reviews 20, 231-247.

Brookes, P.C., Landman, A., Pruden, G., Jenkinson, D.S., 1985. Chloroform fumigation and the release of soil nitrogen: a rapid extraction method to measure microbial biomass nitrogen in soil. Soil Biology \& Biochemistry 17, 837-842.

Bruckner, A., Kandeler, E., Kampichler, C., 1999. Plot-scale spatial patterns of soil water content, $\mathrm{pH}$, substrate-induced respiration and $\mathrm{N}$ mineralization in a temperate coniferous forest. Geoderma 93, 207-223.

Cameron, K.C., Smith, N.P., McLay, C.D.A., Fraser, P.M., McPherson, P.J., Harrison, D.F., Harbottle, P., 1992. Lysimeters without edge-flow: an improved design and sampling procedure. Soil Science Society of America Journal 56, 1625-1628.

Cookson, W.R., Rowarth, J.S., Cameron, K.C., 2001. The fate of autumn-, late winter- and springapplied nitrogen fertilizer in a perennial ryegrass (Lolium perenne L.) seed crop on a silt loam soil in Canterbury, New Zealand. Agriculture, Ecosystems \& Environment 84, 67-77. 
Corre, M.D., Schnabel, R.R., Stout, W.L., 2002. Spatial and seasonal variation of gross nitrogen transformations and microbial biomass in a Northeastern US grassland. Soil Biology \& Biochemistry 34, 445-457.

de Boer, W., Klein Gunnewiek, P.J.A., Parkinson, D., 1996. Variability of N mineralization and nitrification in a simple, simulated microbial forest soil community. Soil Biology \& Biochemistry 28, 203-211.

Di, H.J., Cameron, K.C., Moore, S., Smith, N.P., 1998. Nitrate leaching and pasture yields following the application of dairy shed effluent or ammonium fertilizer under spray or flood irrigation: results of a lysimeter study. Soil Use \& Management 14, 209-214.

Di, H.J., Cameron, K.C., 2002. The use of nitrification inhibitor, dicyandiamide (DCD), to decrease nitrate leaching and nitrous oxide emissions in a simulated grazed and irrigated grassland. Soil Use \& Management 18, 395-403.

Ettema, C.H., Wardle, D.A., 2002. Spatial soil ecology. Trends in Ecology \& Evolution 17, $177-$ 183.

Ettema, C.H., Yeates, G.W., 2003. Nested spatial biodiversity patterns of nematode genera in a New Zealand forest and pasture soil. Soil Biology \& Biochemistry 35, 339-342.

Franklin, R.B., Blum, L.K., McComb, A.C., Mills, A.L., 2002. A geostatistical analysis of smallscale spatial variability in bacterial abundance and community structure in salt marsh creek bank sediments. FEMS Microbiology Ecology 42, 71-80.

Fraser, P.M., Cameron, K.C., Sherlock, R.R., 1994. Lysimeter study of the fate of nitrogen in animal urine returns to irrigated pasture. European Journal of Soil Science 45, 439-447.

Goovaerts, P., 1998. Geostatistical tools for characterizing the spatial variability of microbiological and physico-chemical soil properties. Biology \& Fertility of Soils 27, 315-334.

Harden, T., Joergensen, R.G., 2000. Relationships between simulated spatial variability and some estimates of microbial biomass turnover. Soil Biology \& Biochemistry 32, 139-142.

Insam, H., Rangger, A., 1997. Microbial communities: functional vs. structural approaches. Springer Verlag, Berlin. 263 pp.

Kennedy, A.C., Gewin, V.L., 1997. Soil microbial diversity: Present and future considerations. Soil Science 162, 607-617.

Legendre, P., Legendre, L., 1998. Numerical Ecology. Elsevier, Amsterdam, The Netherlands. 870 pp.

Morris, S.J., 1999. Spatial distribution of fungal and bacterial biomass in southern Ohio hardwood forest soils: fine scale variability and microscale patterns. Soil Biology \& Biochemistry 31 , $1375-1386$.

Nunan, N., Wu, K., Young, I.M., Crawford, J.W., Ritz, K., 2002. In situ spatial patterns of soil bacterial populations, mapped at multiple scales, in arable soil. Microbial Ecology 44, 296-305.

O'Donnell, A.G., Seasman, M., Macrae, A., Waite, I., Davies, J.T., 2001. Plants and fertilisers as drivers of change in microbial community structure and function in soils. Plant \& Soil 232, $135-145$.

Riley, N.G., Zhao, F.J., McGrath, S.P., 2002. Leaching losses of sulphur from different forms of sulphur fertilizers: a field lysimeter study. Soil Use \& Management 18, 120-126.

Ritz, K., Dighton, J., Giller, K.E., 1994. Beyond the Biomass: compositional and functional analysis of soil microbial communities. John Wiley \& Sons, Inc., Chichester. 275 pp. 
Röver, M., Kaiser, E.-A., 1999. Spatial heterogeneity within the plough layer: low and moderate variability of soil properties. Soil Biology \& Biochemistry 31, 175-187.

Søvik, A.K., Aagaard, P., 2003. Spatial variability of a solid porous framework with regard to chemical and physical properties. Geoderma 113, 47-76.

Sparling, G.P., West, A.W., 1988. Modifications to the fumigation extraction technique to permit simultaneous extraction and estimation of soil microbial C and N. Communications in Soil Science \& Plant Analysis 19, 327-344.

Sparling, G.P., Feltham, C.W., Reynolds, J., West, A.W., Singleton, P., 1990. Estimation of soil microbial $\mathrm{C}$ by a fumigation-extraction method: use on soils of high organic matter content, and a reassessment of the $k_{\mathrm{ec}}$-factor. Soil Biology \& Biochemistry 22, 301-307.

Stein, A., Ettema, C.H., 2003. An overview of spatial sampling procedures and experimental design of spatial studies for ecosystem comparisons. Agriculture, Ecosystems \& Environment 94, 31 47.

Stout, W.L., Fales, S.L., Muller, L.D., Schnabel, R.R., Weaver, S.R., 2000. Water quality implications of nitrate leaching from intensively grazed pasture swards in the northeast US. Agriculture, Ecosystems \& Environment 77, 203-210.

Turner, B.L., Haygarth, P.M., 2000. Phosphorus forms and concentration in leachate under four grassland soil types. Soil Science of America Journal 64, 1090-1099.

Waldrop, M.P., Balser, T.C., Firestone, M.K., 2000. Linking microbial community composition to function in a tropical soil. Soil Biology \& Biochemistry 32, 1837-1846. 


\section{Table 1}

Results of ANOVA based on levels of eight selected parameters and their ratios. Displayed are levels of significance for the effects of position (area), area (site) and site, as well as comparisons of mean square values (MSq).

\begin{tabular}{lllll}
\hline Soil property & Position (area) & Area (site) & Site & MSq \\
\hline $\mathrm{C}_{\mathrm{mic}}\left(\mu \mathrm{g} \mathrm{C} \mathrm{g}^{-1}\right.$ soil) & $* * *$ & $* *$ & $\mathrm{NS}$ & area (site) $>$ site \\
$\mathrm{N}_{\text {mic }}\left(\mu \mathrm{g} \mathrm{C} \mathrm{g}^{-1}\right.$ soil) & $* * *$ & $* * *$ & $*$ & area (site) $>$ site \\
$\mathrm{ADA}\left(\mu \mathrm{g} \mathrm{NH}_{4}-\mathrm{N} \mathrm{g}^{-1} \mathrm{~h}^{-1}\right)$ & $* * *$ & $\mathrm{NS}$ & $* *$ & site $>$ area (site) \\
$\mathrm{C}_{\mathrm{mic}} / \mathrm{N}_{\mathrm{mic}}$ & $* * *$ & $* * *$ & $* * *$ & site $>$ area (site) \\
$\mathrm{C}_{\mathrm{mic}} / \mathrm{C}_{\text {tot }}(\%)$ & $\mathrm{ND}$ & $* * *$ & $* * *$ & site $>$ area (site) \\
$\mathrm{C}_{\text {tot }}(\%)$ & $\mathrm{ND}$ & $\mathrm{NS}$ & $* * *$ & site $>$ area (site) \\
$\mathrm{N}_{\text {tot }}(\%)$ & $\mathrm{ND}$ & $\mathrm{NS}$ & $* * *$ & site $>$ area (site) \\
$\mathrm{C} / \mathrm{N}$ & $\mathrm{ND}$ & $* * *$ & $* * *$ & site $>$ area (site) \\
\hline
\end{tabular}

Position (area): positions within each area; Area (site): areas within each site; $* * *, \mathrm{P}<0.001 ; * *$, $\mathrm{P}<0.01$; * $\mathrm{P}<0.05$; NS, not significant; ND, not determined; $\mathrm{N}=60$ for area (site) and site; $\mathrm{N}=120$ for position (area) (For $\mathrm{C}_{\text {tot }}, \mathrm{N}_{\text {tot }}, \mathrm{C} / \mathrm{N}$ and $\mathrm{C}_{\text {mic }} / \mathrm{C}_{\text {tot }} \mathrm{N}=60$ for position (area) which makes statistical analysis impossible.).

\section{Table 2}

Levels of selected soil properties in ORG and CON and significance of the effect site.

\begin{tabular}{llll}
\hline Soil property & ORG & CON & Site effect \\
\hline $\mathrm{C}_{\text {mic }}\left(\mu \mathrm{g} \mathrm{C} \mathrm{g}^{-1}\right.$ soil $)$ & $460.8(16.1)$ & $502.6(16.1)$ & $\mathrm{NS}$ \\
$\mathrm{N}_{\text {mic }}\left(\mu \mathrm{g} \mathrm{C} \mathrm{g}^{-1}\right.$ soil $)$ & $62.7(2.36)$ & $54.6(2.36)$ & $*$ \\
$\mathrm{ADA}\left(\mu \mathrm{g} \mathrm{NH}_{4}-\mathrm{N} \mathrm{g}^{-1} \mathrm{~h}^{-1}\right)$ & $0.96(0.047)$ & $0.74(0.047)$ & $* *$ \\
$\mathrm{C}_{\text {mid }} / \mathrm{N}_{\text {mic }}$ & $7.77(0.30)$ & $9.61(0.30)$ & $* * *$ \\
$\mathrm{C}_{\text {mid }} / \mathrm{C}_{\text {tot }}(\%)$ & $2.02(0.043)$ & $1.77(0.043)$ & $* * *$ \\
$\mathrm{C}_{\text {tot }}(\%)$ & $2.27(0.042)$ & $2.84(0.042)$ & $* * *$ \\
$\mathrm{~N}_{\text {tot }}(\%)$ & $0.19(0.004)$ & $0.24(0.004)$ & $* * *$ \\
$\mathrm{C} / \mathrm{N}$ & $12.3(0.048)$ & $11.5(0.048)$ & $* * *$ \\
\hline
\end{tabular}

Values are mean (standard error of mean in brackets); ***, $\mathrm{P}<0.001 ;{ }^{* *}, \mathrm{P}<0.01 ; *, \mathrm{P}<0.05$; NS, not significant; $\mathrm{N}=60$. 
Table 3

Significance of the effects of position (area), area (site), and site on average log-transformed values of biotic $\left(\mathrm{C}_{\text {mic }}, \mathrm{N}_{\text {mic }}, \mathrm{ADA}, \mathrm{C}_{\mathrm{mic}} / \mathrm{N}_{\text {mic }}\right)$ and abiotic $\left(\mathrm{C}_{\text {tot }}, \mathrm{N}_{\mathrm{tot}}, \mathrm{C} / \mathrm{N}\right)$ soil properties.

\begin{tabular}{lll}
\hline & biotic & abiotic \\
\hline position (area) & $* * *$ & $\mathrm{ND}$ \\
area (site) & $* *$ & $\mathrm{NS}$ \\
site & $\mathrm{NS}$ & $* * *$ \\
\hline
\end{tabular}

position (area): positions within each area; area (site): areas within each site.

NS, not significant; ND, not determined.

\section{Table 4}

Descriptive statistics for frequency distribution of $\mathrm{C}_{\text {mic }}, \mathrm{N}_{\text {mic }}, \mathrm{ADA} .\left(\mathrm{A}^{2}, \mathrm{P}\right.$ : Anderson-Darling Normality Test).

\begin{tabular}{llll}
\hline & $\begin{array}{l}\mathrm{C}_{\text {mic }} \\
\left(\mu \mathrm{C} \mathrm{g}^{-1} \text { soil }\right)\end{array}$ & $\begin{array}{l}\mathrm{N}_{\text {mic }} \\
\left(\mu \mathrm{g} \mathrm{g} \mathrm{g}^{-1} \text { soil }\right)\end{array}$ & $\begin{array}{l}\text { ADA } \\
\left(\mu \mathrm{NH}_{4}-\mathrm{N} \mathrm{g}^{-1} \mathrm{~h}^{-1}\right)\end{array}$ \\
\hline $\mathrm{A}^{2}$ & 0.320 & 0.394 & 1.14 \\
$\mathrm{P}$ & 0.524 & 0.365 & 0.005 \\
Mean & 481.7 & 58.6 & 0.851 \\
StDev & 97.4 & 16.4 & 0.284 \\
Skewness & 0.218 & 0.323 & 1.49 \\
Median & 480.6 & 59.0 & 0.799 \\
SE & 12.6 & 2.1 & 0.037 \\
$\mathrm{CV} \%$ & 0.736 & 2.52 & 2.5 \\
\hline
\end{tabular}




\section{Table 5}

Parameters of autocorrelation in $\mathrm{C}_{\text {mic }}, \mathrm{N}_{\text {mic }}$ and ADA based on best-fit lines derived from exponential model (Eq. 1)

\begin{tabular}{llllllll}
\hline & & $\begin{array}{l}\text { Nugget } \\
\left(\mathrm{C}_{0}\right)\end{array}$ & $\begin{array}{l}\text { Sill } \\
\left(\mathrm{C}=\mathrm{C}_{0}+\mathrm{C}_{1}\right)\end{array}$ & $\begin{array}{l}\text { Spatial } \\
\text { dependence }\end{array}$ & $\mathrm{R}^{2}$ & $\mathrm{P}$ & $\begin{array}{l}\text { range } \\
(\mathrm{cm})\end{array}$ \\
\hline $\mathrm{C}_{\text {mic }}$ & ORG & 824 & 16292 & 0.95 & 0.99 & 0.001 & 43 \\
& CON & 1110 & 3075 & 0.64 & 0.98 & 0.018 & 31 \\
& average & 958 & 8788 & 0.89 & 0.98 & 0.003 & 13 \\
$\mathrm{~N}_{\text {mic }}$ & ORG & 21 & 333 & 0.94 & 0.99 & 0.002 & 31 \\
& CON & 27 & 61 & 0.56 & 0.96 & 0.04 & 25 \\
& average & 23 & 184 & 0.88 & 0.99 & $<0.001$ & 22 \\
& ORG & 0.023 & 0.126 & 0.82 & 0.81 & 0.082 & 179 \\
& CON & 0.016 & 0.028 & 0.44 & 0.67 & 0.327 & 48 \\
& average & 0.019 & 0.047 & 0.60 & 0.81 & 0.081 & 36 \\
\hline
\end{tabular}

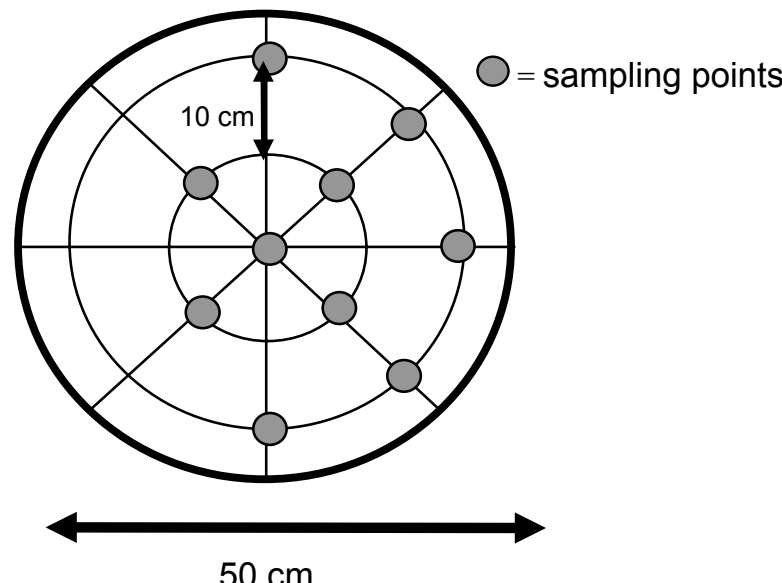

Fig. 1.

Sampling regime for spatial pattern determination.

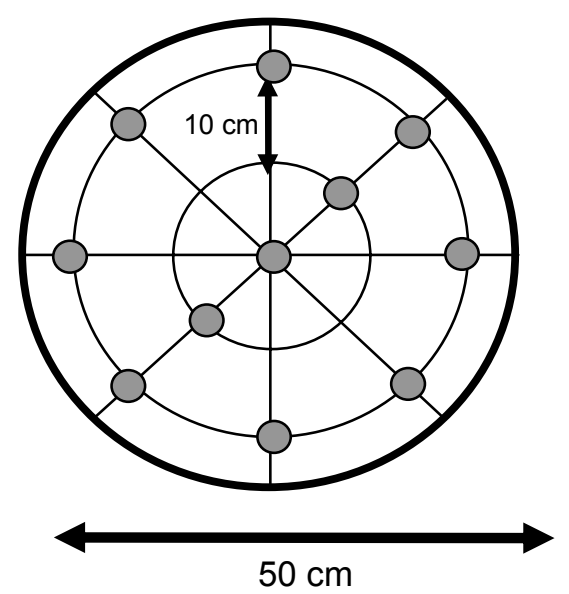

Fig. 4.

Revised strategy for regular soil sampling from lysimeters. 




Fig. 2.

Coefficients of variance at different levels of variability for eight soil properties and their averages (position $=$ variance between ten positions within each area; area $=$ variance among three replicates within each site; site $=$ variance between the sites $\mathrm{ORG}$ and $\mathrm{CON})$ : $\mathrm{Cmic}=$ microbial $\mathrm{C}$; $\mathrm{Nmic}=$ microbial $\mathrm{N} ; \mathrm{ADA}=$ arginine deaminase activity; $\mathrm{Cmic} / \mathrm{Nmic}=$ microbial carbon: microbial nitrogen ratio; $\mathrm{Cmic} / \mathrm{Ctot}=$ microbial quotient; $\mathrm{Ctot}=$ total $\mathrm{C} ; \mathrm{Ntot}=$ total $\mathrm{N} ; \mathrm{C} / \mathrm{N}=$ carbon: nitrogen ratio; moisture $=$ soil moisture content; biotic $=$ average of biological soil properties $\left(\mathrm{C}_{\text {mic }}\right.$; $\left.\mathrm{N}_{\text {mic }} ; \mathrm{ADA} ; \mathrm{C}_{\mathrm{mic}} / \mathrm{N}_{\text {mic }}\right)$; abiotic $=$ average of chemical soil properties $\left(\mathrm{C}_{\text {tot }} ; \mathrm{N}_{\text {tot }} ; \mathrm{C} / \mathrm{N}\right)$. 



Fig. 3.

Patterns of semivariance $(\gamma)$ in $\mathrm{C}_{\text {mic }}$ and $\mathrm{N}_{\text {mic }}$ and in ADA with increasing distance (h) between sampling points for ORG (distance classes 0-40 cm), CON $(0-30 \mathrm{~cm})$ and average $(0-40 \mathrm{~cm})$. Bestfit lines (based on exponential model) are shown for ORG, $C O N$ and average. $(\mathrm{ORG}, \mathrm{CON}=$ average of three replicates, average $=$ overall average). 